\title{
Clinical and epidemiological aspects of feline leishmaniasis in Brazil
}

\section{Aspectos clínicos e epidemiológicos da leishmaniose felina no Brasil}

\author{
Luiz da Silveira Neto'; Mary Marcondes ${ }^{2}$; Elizabeth Bilsland ${ }^{3}$; Lucas Vinícius \\ Shigaki de Matos ${ }^{1}$; Milena Araúz Viol ${ }^{4}$; Katia Denise Saraiva Bresciani ${ }^{5}$
}

\begin{abstract}
Tegumentary and visceral leishmaniasis are severe and unfortunately common parasitic diseases in Brazil. Among domestic animals, dogs are considered the main urban reservoir of the protozoan parasites, however, there is evidence that infected cats can also contribute towards the disease pool. The number of cats diagnosed with leishmaniasis has greatly increased in the last few years, highlighting the importance of thorough investigations on the role of the cat in the epidemiological cycle of the disease and in public health related issues. The main clinical manifestations of leishmaniasis suffered by cats, even when infected with Leishmania chagasi, a viscerotropic species, are skin abnormalities, which can be confounded with multiple other diseases. Indirect ELISA should be used as a screening test in epidemiological investigations for being a sensitive technique, followed by more specific laboratory tests. The standardization and validation of rapid, economical and reproducible diagnostic methods, to be employed in epidemiological surveillance, are still required.
\end{abstract}

Key words: Leishmania spp., cat, epidemiology, diagnosis, zoonosis, prevalence

\section{Resumo}

Leishmaniose tegumentar e visceral são doenças parasitárias graves e, infelizmente, comuns no Brasil. Entre os animais domésticos, o cão é considerado o principal reservatório urbano do parasito protozoário; no entanto, há indícios de que gatos infectados também possam contribuir para essas doenças. O número de gatos com diagnóstico de leishmaniose aumentou muito nos últimos anos, destacando a importância de investigações aprofundadas sobre o papel desse hospedeiro no ciclo epidemiológico da doença e em Saúde Pública. As principais manifestações clínicas da leishmaniose felina são anormalidades na pele, o que pode ser confundida com várias outras doenças, mesmo em casos de infecção por Leishmania chagasi, uma espécie viscerotrópica. ELISA indireto poderia ser usado como teste de triagem em investigações epidemiológicas, por ser um método sensível, seguido de exames laboratoriais mais específicos. A padronização e validação de métodos de diagnóstico rápidos, econômicos e reprodutíveis a serem empregados na vigilância epidemiológica ainda são necessárias.

Palavras-chave Leishmania spp., gato, epidemiologia, diagnóstico, zoonose, prevalência

\footnotetext{
1 Discentes, Programa de Pós-Graduação em Medicina Veterinária. Universidade Estadual Paulista, FCAV, Jaboticabal, SP, Brasil. E-mail: luiz.silveira@gmail.com; lucasvsm@hotmail.com

2 Prof ${ }^{a}$, Universidade Estadual Paulista, FMVA, Dept ${ }^{\circ}$ Clínica, Cirurgia e Reprodução Animal, DCCRA, Araçatuba, SP, Brasil. E-mail: marcondes@fmva.unesp.br

3 Prof ${ }^{a}$, Cambridge Systems Biology Center, University of Cambridge, Cambridge, United Kingdom. Department of Structural and Functional Biology, Institute of Biology, UNICAMP, Campinas, SP, Brazil. E-mail: eb343@cam.ac.uk

4 Discente, Programa de Pós-Graduação em Ciência Animal, Universidade Estadual Paulista, FMVA, Araçatuba, SP, Brasil. E-mail: milenaviol@hotmail.com

5 Prof., Universidade Estadual Paulista, FMVA, Dept ${ }^{\circ}$ Clínica, Cirurgia e Reprodução Animal, DCCRA, Araçatuba, SP, Brasil. E-mail: bresciani@fmva.unesp.br

* Author for correspondence
} 


\section{Introduction}

Leishmaniasis is a protozoan disease caused by parasites of the genus Leishmania. Leishmaniasis is commonly classified in two clinical forms: tegumentary leishmaniasis (TL) or visceral leishmaniasis (VL), depending on the species of Leishmania causing the infection (CASTRO, 1996; DESJEUX, 2004; BRASIL, 2006a, 2006b).

The main route of VL transmission in America is through blood meals of the female Lutzomyia longipalpis and Lutzomyia cruzi species, which belong to the Psychodidae family (CHAGAS, 1940; SANTOS et al., 1998). Among domestic animals, dogs are the main urban reservoir of the protozoan parasite (ALENCAR et al., 1991). Hence, to decrease the spread of the protozoa and the incidence of human VL, this host is the target of stringent actions: early diagnosis and euthanasia of seropositive dogs (BRASIL, 2014).

Recently, reports of feline leishmaniasis increased dramatically, achieving a prevalence of up to $61 \%$ in certain cat populations (PENNISI et al., 2000). This phenomenon could be explained by three hypotheses: increase in the active investigation of the protozoan in this host, improvement of the diagnostic techniques, and current increase in the rate of disease prevalence in domestic cats.
The aim of this literature review is to describe the etiology, prevalence, clinical signs, and diagnosis of feline leishmaniasis, and highlight the importance of cats as a leishmaniasis host in Brazil.

\section{Historical background}

The first feline infection with Leishmania sp. was described in Algeria (SERGENT et al., 1912). In the subsequent years, researchers continued to actively investigate the presence of the protozoan in cats in Italy (GIORDANO, 1933), Spain (GIMENOONDOVILLA, 1933) and Brazil (DEANE, 1956).

In the $80 \mathrm{~s}$, after the cytological detection of Leishmania sp. in $20.5 \%$ of 78 samples of feline spleens and livers, the highest sample prevalence until then, diagnostic studies of leishmaniasis in cats were intensified (MORSY et al., 1980). In 1985, the first case of co-infection with HIV and Leishmania donovani was reported in humans, an event that led the World Health Organization to significantly increase Leishmania epidemiological surveillance (WHO, 2007). Therefore, in mid-2000, research on feline leishmaniasis was intensified both at international level (Table 1) and in Brazil (Table 2).

Table 1. Chronological order of the occurrence of feline leishmaniasis in several countries illustrated by description of cases (D) or epidemiological studies (I), using different diagnostic techniques.

\begin{tabular}{lllll}
\hline Country & D/I & Technique $^{\mathbf{1}}$ & Prevalence (\%) $^{\text {Reference }}$ \\
\hline Algeria & $\mathrm{D}$ & - & $1 / 1(100)$ & (SERGENT et al., 1912) \\
Italy & I & Cytol., Hist. & $0 / 120(0.0)$ & (GIORDANO, 1933) \\
Spain & I & - & $1 / 495(0.2)$ & (GIMENO-ONDOVILLA, 1933) \\
Jordan & I & Cytol. & $16 / 78(20.5)$ & (MORSY et al., 1980) \\
Egypt & I & IH & $3 / 80(3.7)$ & (MICHAEL et al., 1982) \\
Egypt & I & IH & $1 / 28(3.6)$ & (MORSY et al., 1988) \\
France & I & IFAT & $1 / 174(0.6)$ & (BEZ; CHAUVE, 1992) \\
Egypt & I & IH & $2 / 60(3.3)$ & (MORSY; ABOU El SEOUD, 1994) \\
France & I & WB & $12 / 97(12.4)$ & (OZON et al., 1998) \\
Spain & D & Cytol.,RIFI & $2 / 2(100)$ & (HERVÁS et al., 1999) \\
Italy & I & PCR, IFAT & $54 / 89(60.6)$ & (PENNISI et al., 2000)
\end{tabular}


continuação

\begin{tabular}{|c|c|c|c|c|}
\hline Country & $\mathbf{D} / \mathbf{I}$ & Technique $^{1}$ & Prevalence (\%) & Reference \\
\hline Italy & I & IFAT & $1 / 110(0.9)$ & (POLI et al., 2002) \\
\hline Spain & $\mathrm{D}$ & IFAT, PCR & $4 / 4(100)$ & (PENNISI et al., 2004) \\
\hline Italy & I & IFAT & $33 / 203(16.3)$ & (VITA et al., 2005) \\
\hline Spain & $\mathrm{D}$ & ELISA & $1 / 1(100)$ & (LEIVA et al., 2005) \\
\hline Switzerland & $\mathrm{D}$ & Hist., PCR, ELISA & $2 / 2(100)$ & (RÜFENACHT et al., 2005) \\
\hline Mediterranean & I & $\begin{array}{l}\text { ELISA - protein A } \\
\text { ELISA - IgG }\end{array}$ & $\begin{array}{l}28 / 445(6.3) \\
23 / 445(5.3)\end{array}$ & (SOLANO-GALLEGO et al., 2007) \\
\hline Spain & I & $\begin{array}{l}\text { IFAT } \\
\text { PCR-ELISA }\end{array}$ & $\begin{array}{l}52 / 183(28.3) \\
47 / 183(25.7)\end{array}$ & (MARTÍN-SÁNCHEZ et al., 2007) \\
\hline Israel & I & ELISA & $7 / 104(6.7)$ & (NASEREDDIN et al., 2008) \\
\hline Spain & I & $\begin{array}{l}\text { IFAT } \\
\text { PCR }\end{array}$ & $\begin{array}{l}3 / 233(1.3) \\
1 / 233(0.4)\end{array}$ & (AYLLON et al., 2008) \\
\hline Spain & I & PCR & $3 / 100(3.0)$ & (TABAR et al., 2008) \\
\hline Portugal & I & $\begin{array}{l}\text { IFAT } \\
\text { PCR }\end{array}$ & $\begin{array}{l}0 / 20(0.0) \\
7 / 23(30.4)\end{array}$ & (MAIA et al., 2008) \\
\hline Iran & I & IFAT, PCR, Cytol., Cult. & $4 / 40(10.0)$ & (HATAM et al., 2010) \\
\hline Greece & I & ELISA & $11 / 284(3.9)$ & (DIAKOU et al., 2009) \\
\hline Portugal & I & $\begin{array}{l}\text { DAT } \\
\text { ELISA }\end{array}$ & $\begin{array}{l}6 / 316(1.9) \\
9 / 316(2.8)\end{array}$ & (CARDOSO et al., 2010) \\
\hline French Guiana & $\mathrm{D}$ & PCR & $1 / 1(100)$ & (ROUGERON et al., 2011) \\
\hline Mexico & I & $\begin{array}{l}\text { ELISA-CAG } \\
\text { ELISA-Fe-SODe }\end{array}$ & $\begin{array}{l}17 / 95(17.9) \\
34 / 95(35.8)\end{array}$ & (LONGONI et al., 2012) \\
\hline
\end{tabular}

${ }^{1}$ Cytol.: cytology, Hist.: histopathology, IH: indirect hemagglutination, WB: western blot, RIFI: indirect fluorescence antibody test, PCR: polymerase chain reaction, ELISA: enzyme-linked immunosorbent assay, DAT: direct agglutination test, ELISA-CAG: crude antigen ELISA, Cult.: isolation and biological culture, ELISA-Fe-SODe: iron superoxide dismutase secreted antigen ELISA.

Table 2. Chronological order of the occurrence of feline leishmaniasis illustrated by description of cases (D) or epidemiological studies (I), using different diagnostic methods in Brazil.

\begin{tabular}{llll}
\hline D/I & Technique $^{\mathbf{1}}$ & Prevalence (\%) & Reference \\
\hline I & Cytol. & $1 / 202(0.5)$ & (CHAGAS et al., 1938) \\
I & Cytol. & $0 / 142(0.0)$ & (DEANE, 1956) \\
I & Hist. & $1 / 53(1.9)$ & (SHERLOCK, 1996) \\
I & IFAT & $0 / 53(0.0)$ & (SHERLOCK, 1996) \\
I & ELISA & $9 / 84(10.7)$ & (SIMÕES-MATTOS et al., 2001) \\
D & Cytol.,PCR & $1 / 1(100)$ & (SAVANI et al., 2004) \\
D & Cult., Hist. & $2 / 2(100)$ & (SCHUBACH et al., 2004) \\
D & Cytol. & $1 / 1(100)$ & (de SOUZA et al., 2005) \\
I & IFAT & $2 / 8(25.0)$ & (da SILVA et al., 2008) \\
I & PCR & $2 / 8(25.0)$ & (SILVA et al., 2008) \\
D & IFAT, ELISA, PCR & $1 / 1(100)$ & (SERRANO et al., 2008) \\
D & Cytol. & $1 / 1(100)$ & (de SOUZA et al., 2009) \\
I & IFAT & $0 / 43(0.0)$ & (FIGUEIREDO et al., 2009) \\
I & ELISA & $1 / 43(2.4)$ & (FIGUEIREDO et al., 2009) \\
I & Cytol. & $8 / 200(4.0)$ & (COSTA et al., 2010)
\end{tabular}


continuação

\begin{tabular}{llll}
\hline D/I & Technique $^{\mathbf{1}}$ & Prevalence (\%) & Reference \\
\hline I & ELISA & $23 / 200(11.5)$ & (COSTA et al., 2010) \\
I & Cytol. & $2 / 283(0.7)$ & (BRESCIANI et al., 2010) \\
I & IFAT & $0 / 283(0.0)$ & (BRESCIANI et al., 2010) \\
I & ELISA-CAG & $26 / 113(23.0)$ & (da SILVEIRA NETO et al., 2011) \\
& ELISA-FML & $15 / 113(13.3)$ & (SILVEIRA NETO et al., 2011) \\
I & ELISA-rK39 & $18 / 113(15.9)$ & (VIDES et al., 2011) \\
& ELISA & $14 / 55(25.4)$ & \\
& RIFI & $6 / 55(10.9)$ & (VIDES et al., 2011) \\
I & IH & $9 / 55(16.4)$ & (COELHO et al., 2011) \\
I & Cytol. & $10 / 55(18.2)$ & \\
& PCR & $3 / 52(5.8)$ & (SOBRINHO et al., 2012) \\
I & Cytol. & $30 / 302(9.9)$ & (SOBRINHO et al., 2012) \\
I & ELISA & $39 / 302(12.9)$ & (CARDIA et al., 2013) \\
I & RIFI & $14 / 302(4.6)$ & \\
\hline
\end{tabular}

${ }^{1}$ Citol.: cytology, Histopathol.: histopathology, IH: indirect hemagglutination, DAT: direct agglutination test, IFAT: indirect fluorescence antibody test, IH: immunohistochemistry, ELISA: enzyme-linked immunosorbent assay, PCR: polymerase chain reaction, Cult.: isolation and biological culture, ELISA-CAG: crude antigen ELISA, ELISA-FML: fucose-mannose ligand antigen ELISA, ELISA-rK9: recombinant K39 antigen ELISA.

\section{Etiology}

The causative agent of leishmaniasis belongs to the kingdom Excavata, superphylum Discoba, phylum Euglenozoa, class Kinetoplastea, subclass Metakinetoplastina, order Trypanosomatida, suborder Trypanosomatina, family Trypanosomatidae, order Trypanosomatidae, family Metakinetoplastina, and genus Leishmania (ADL et al., 2012), which is divided in two subgenera, Leishmania and Viannia, according to the location of the protozoa in the digestive tract of the vector (WHO, 2010).

The Leishmania subgenus includes four complexes: Leishmania donovani (species: $L$. donovani, $L$. archibaldi, and $L$. infantum [syn. $L$. chagasi]), Leishmania. tropica (species: L. tropica, L. killicki, and L. aethiopica), Leishmania. major (species: L. major, L. gerbilli, L. arabica, and $L$. turanica) and Leishmania mexicana (species: $L$. mexicana [syn. L. pifanoi], L. amazonensis [syn. L. garnhami], L. aristidesi, L. venezuelensis, and L. forattini). Although L. enrietti belongs to this subgenus, it is not yet included in any of these complexes. Among the mentioned species, only infections caused by the L. mexicana complex and L. chagasi species have been reported in the New World (SCHÖNIAN et al., 2010).

The Viannia subgenus, which only causes infections on the New World, includes two complexes: Leishmania braziliensis (species: L. braziliensis and L. peruviania) and Leishmania guyanensis (species: L. guyanensis, L. panamensis, and $L$. shawi). Other species, such as $L$. naiffi, $L$. lainsoni, L. lindenbergi, and L. utingensis, also belong to this subgenus, but have not yet been classified into any particular complex (SCHÖNIAN et al., 2010).

Five other Leishmania species (L. colombiensis, L. equatoriensis, L. hertigi, L. herreri, and L. deanei (SCHÖNIAN et al., 2010)), which due to their low homology do not belong to either of these subgenera, are known as Paraleishmania (CUPOLILLO et al., 2000). 
Currently, the taxonomy of the Leishmania genus is highly debated. In the future, the classification of this protozoan would probably benefit from a molecular characterization and classification based on genome sequencing (FRAGA et al., 2010; SCHÖNIAN et al., 2010; VAN DER AUWERA et al., 2011).

\section{Epidemiology and Public Health}

Leishmaniasis occurs in 98 countries (WHO, 2010), affecting 1.2 million (tegumentary leishmaniasis) and 400 thousand (visceral leishmaniasis) people, thus leading to approximately 40 thousand deaths per year. TL is distributed worldwide but VL affects mainly ( $90 \%$ of cases) six countries: India, Bangladesh, Sudan, South Sudan, Ethiopia, and Brazil (ALVAR et al., 2012).

Between 1980 and 2005, more than 59 thousand cases of VL infections were reported in Brazil, $83 \%$ of which were diagnosed in the Northeastern region of the country. In the $80 \mathrm{~s}$, human Leishmania infections were reported in 19 states of Brazil. In 2003, $45 \%$ of the infections were reported in the Northern region, predominantly in the states of Pará, Amazonas and Rondônia, 26\% of the infections were reported in the Northeastern region, mainly affecting the states of Maranhão, Bahia and Ceará, $15 \%$ of the infections were reported in the Midwestern region, mainly affecting the state of Mato Grosso, $11 \%$ of the infections were reported in the Southeastern region, mainly affecting the state of Minas Gerais and 3\% of the infections were reported in the Southern region, mainly affecting the state of Paraná. Currently, the disease is distrubuted throughout the entire national territory (BRASIL, 2006b; MAIA-ELKHOURY et al., 2008).

In Brazil, VL is caused by L. chagasi (BRASIL, 2014) while TL is caused by $L$. braziliensis, $L$. guyanensis, L. amazonensis, L. lainsoni, L. naiff, and L. shawi (BRASIL, 2006a). Among these species, three have already been isolated in Brazilian cats: L. braziliensis (SCHUBACH et al., 2004), L. amazonensis (SOUZA et al., 2005), and L. chagasi (VIDES et al., 2011), whereas L. venezuelensis (BONFANTE-GARRIDO et al., 1996) and $L$. mexicana (TRAINOR et al., 2010) infect cats in other countries.

Malnourished and immunosuppressed humans are more susceptible to severe forms of these diseases (ASHFORD, 2000; BRASIL, 2014; GONTIJO, MELO, 2004; DAHER et al., 2009; TRAINOR et al., 2010), which especially affects patients with Acquired Immunodeficiency Syndrome (WHO, 2010). As in humans, cats with Feline Immunodeficiency Virus (FIV) are more predisposed to develop leishmaniasis (PENNISI et al., 2012). Moreover, age is a predisposing factor for the disease, as cats over three years are more likely to be infected by Leishmania sp. (PENNISI et al., 2012), probably due to a longer exposure to infected vectors.

Cats infected by $L$. donovani and $L$. infantum may be urban reservoirs of visceral leishmaniasis, as they can transmit the protozoan to phlebotomine sandflies used in xenodiagnosis (SILVA et al., 2010; MAROLI et al., 2007), and present high parasitism in the skin as assessed by immunohistochemistry (VIDES et al., 2011). Interestingly, in 2004 an autochthonous case of feline visceral leishmaniasis was reported in Cotia - SP, where no cases of canine or human disease had been detected (SAVANI et al., 2004). Only four years later the city became endemic for canine visceral leishmaniasis (BEPA, 2008), but no cases of human infections have been reported in Cotia to date (CVE, 2013).

\section{Biological cycle}

Leishmaniasis is transmitted by phlebotomine sandflies: small insects of the order Diptera, belonging to the Phlebotominae subfamily. Sandflies can be classified in the genera Phlebotomus, Sergentomyia, and Chinus in the Old World and by Lutzomyia in the New World (WHO, 2010). There are approximately 900 known species of sandflies, 
70 of which can be leishmaniasis vectors (READY, 2013). In Brazil, two species of these insects transmit VL: Lu. longipalpis and Lu. cruzi (BRASIL, 2014). TL vectors include the species Lu. flaviscutellata, Lu. whitmani, Lu. umbratilis, Lu. intermedia, Lu. wellcome, Lu. migonei (BRASIL, 2007) Lu. neivai, and Lu. sallesi (SARAIVA et al., 2009).

Leishmania spp. is primarily present in the invertebrate host as an extracellular and flagellate (promastigote) form or as an obligate intracellular form without external flagellum (amastigote) in the vertebrate host (BAÑULS et al., 2007). Phlebotomine sandflies ingest the protozoan while sucking blood from an infected host. The parasite then multiplies in the intestine of the vector, which become infectious between 8 and 20 days later (DESJEUX, 2004). When biting a vertebrate host, the infected vector inoculates metacyclic promastigotes, which are then phagocytosed by macrophages. Within these cells, they become amastigotes and multiply by binary fission. The increased number of intracellular pathogens causes the disruption of the infected macrophages, thus leading to the dissemination of the microorganism to other phagocytic cells, which may be subsequently ingested by another vector (BAÑULS et al., 2007).

The main route of transmission of canine visceral leishmaniasis is through the bite of vectors infected with L. chagasi (BRASIL, 2014), however, alternative routes of transmission have been proposed. Those are: transplacental transmission (ROSYPAL et al., 2005), blood transfusion (FREITAS et al., 2006), and venereal transmission (SILVA et al., 2009). In cats only the transmission via sandflies have been confirmed thus far.

\section{Clinical signs}

Skin changes (papules, nodules, ulcers, erythema, alopecia) are the most frequent clinical signs of Leishmaniasis in cats, regardless of the Leishmania species that caused the infection: dermatotropic or viscerotropic. The head and in particular, the external ears, nasal plane, snout, and peri-ocular regions are the most affected areas, presumably due to their higher exposure to the vectors as they are less covered by fur (BONFANTE-GARRIDO et al., 1996; SIMÕES-MATTOS et al., 2005; VIDES et al., 2011).

Systemic manifestations of leishmaniasis are less frequent, although anorexia, apathy, emesis, diarrhea, dehydration, weight loss, and stomatitis may occur (OZON et al., 1998; HERVÁS et al., 1999; POLI et al., 2002; LEIVA et al., 2005). Approximately $30 \%$ of the cats infected with $L$. chagasi present only dermatosis. The frequency of lymphadenopathy, commonly developed by dogs with visceral leishmaniasis (CÂNDIDO, 2007), varies in infected cats from 3\% (PENNISI, 2002) to $53 \%$ (VIDES et al., 2011). Ocular alterations (POLI et al., 2002) such as edema and corneal ulcers, purulent uveitis, and eyelid nodules (LEIVA et al., 2005) have also been reported in cats. Feline visceral leishmaniasis may assume an acute atypical form that causes the animal to die in a few weeks (OZON et al., 1998).

The incubation time and the clinical course of the disease in human and dogs are highly influenced by properties of the parasite and by the competence of the host immune system to develop a humoral or cellular immune response (GENARO, 1993; PINELLI et al., 1994). Although domestic cats are relatively resistant to Leishmania infection, mainly due to the fact that they produce a cellular immune response (SOLANO-GALLEGO et al., 2007), the incubation period in these animals is still unknown. After the experimental infection of cats with L. braziliensis, the clinical manifestations of the disease start to appear, on an average, within two weeks (SIMÕES-MATTOS et al., 2005). On the other hand, Simoes-Mattos et al. observed a regression of clinical symptoms, on an average, nine months after the inoculation. During this period, the animals still presented low antibody titers, which suggest a cellular immune response (SIMÕESMATTOS et al., 2005). 
Pennisi et al. (2012) investigated visceral leishmaniasis in cats from an endemic area and found that is possible to amplify, by polymerase chain reaction (PCR), the parasite DNA from the blood of animals negative to the indirect immunofluorescence reaction (RIFI), that is, with antibody titers below 1:80. According to the authors, this suggests the existence of a balance between the host and the parasite achieved by the cellular immune response. However, the animals of this experiment were not monitored over time regarding serology and possible appearance of clinical signs, nor the concentrations of interleukins or other variables related to the cellular immune response were measured. Therefore, studies aiming to better assess the immunity of cats infected with Leishmania sp. are still required.

For a long time, domestic cats were considered accidental hosts of the species causing TL infections, probably because most of the cats infected with Leishmania sp. present exclusively skin changes. Moreover, studies used mainly cytology or antibody detection as diagnostic techniques, which were restricted to identify the parasite genus (SOUZA et al., 2005, 2009; FIGUEIREDO et al., 2009; SILVEIRA NETO et al., 2011). Currently, feline leishmaniasis is assessed by PCR followed by sequencing and genetic alignment, a diagnostic tool that facilitates the identification of the protozoan species. This change in the scientific methodology demonstrated that the VL agent $L$. chagasi is also common in infected Brazilian cats, in spite of their symptoms being predominantly skin abnormalities (SAVANI et al., 2004; COELHO et al., 2011; VIDES et al., 2011; SOBRINHO et al., 2012).

\section{Diagnosis}

In cats, the diagnosis of VL or TL can be divided in: a) epidemiological surveillance and b) clinical and laboratory methods. In the epidemiological surveillance, there is the need for an improvement in the techniques to identify the cause of the clinical signs manifested by the cat, and to subsequently delineate the procedures that should be adopted to control the disease. In the rare cases where leishmaniasis is diagnosed in an epidemiological surveillance, the adoption of diagnostic techniques such as immunohistochemistry and PCR is recommended in the entire cat population, which requires significant logistic and financial resources. For this reason, epidemiological investigations should prioritize sensitive and low cost techniques, such as serological analysis assessed by ELISA or RIFI.

Studies aiming the standardization and validation of serological diagnostic in cats are scarce. One rare exception to this rule is the series of epidemiological studies performed in cats from municipality of Araçatuba, located in the Northwestern region of the state of São Paulo, which is an endemic area for canine and human visceral leishmaniasis (BEPA, 2008). Five years after the disease was first detected in dogs from Araçatuba (LUVIZOTTO et al., 1999), the first case of feline leishmaniasis was diagnosed in this municipality (SERRANO et al., 2008). The animal presented cutaneous injuries, apathy, dehydration, and diarrhea (SERRANO et al., 2008). This finding contributed to the implementation of the largest epidemiological investigation ever carried out in cats in Brazil (ROSSI, 2007). In these studies, the sample prevalence obtained by RIFI and ELISA varied from $0.5 \%$ to $23 \%$, respectively (SILVEIRA NETO et al., 2011; CARDIA et al., 2013), which demonstrates that the serological technique employed may influence the diagnosis. Moreover, a poor correlation of the Kappa coefficient was observed among the techniques of direct detection, such as cytology and immunohistochemistry, and indirect detection, such as RIFI and ELISA (VIDES et al., 2011; SOBRINHO et al., 2012). In general, ELISA showed higher sensitivity when compared to RIFI (VIDES et al., 2011; SOBRINHO et al., 2012), confirming the findings of studies performed in other regions (FIGUEIREDO et al., 2009).

In contrast to infected dogs, cats do not 
present hypergammaglobulinemia, which makes it necessary to use more concentrated serum in ELISA, such as 1:40 (FIGUEIREDO et al., 2009), 1:50 (SILVEIRA NETO et al., 2011), or 1:200 (VIDES et al., 2011, SOBRINHO et al., 2012), compared to a 1:400 dilution used to diagnose the disease in dogs (LIMA et al., 2005). Unfortunately, the use of highly concentrated sera in ELISA may increase the chance of nonspecific reactions, which would influence the reliability of the results.

Silveira Neto et al. (2011) observed very different sample prevalence between the paired sera tested by ELISA using crude antigens (CAG), recombinant K39 antigen (rK39) and fucose-mannose ligand (FML), with values of $23.0 \%, 15.9 \%$, and $13.3 \%$, respectively. Although no significant disagreement was observed between the tests, the correlation between them varied from low to moderate. Crossreaction between antibodies against Toxoplasmoa gondii and the rK39 and FML antigens was detected in $6.7 \%$ of the samples. These results reinforced the hypothesis that ELISA is more sensitive than RIFI, and highlighted the cross-reactivity with antigens of other etiological agents that may lead to false positive results.

In infected dogs, serological techniques can be more sensitive than cytopathologic examinations, with a sensitivity that vary from $50 \%$ to $83 \%$ in bone marrow samples, from $30 \%$ to $85 \%$ in lymph nodes, and from $71 \%$ to $91 \%$ when both tissues of a single individual are assessed in a paired manner (KOUTINAS et al., 2001; MOREIRA et al., 2002). Vides et al. (2011) and Sobrinho et al. (2012) found that $48-50 \%$ of the cats that were seroreactive to ELISA tested negative to RIFI, immunohistochemistry and cytology. Vides et al. (2011) also found that, although amastigote forms of the parasite were identified in $37 \%$ of the infected cats through a biopsy by needle puncture and aspiration (BPA) of the lymphoid organs, $18.5 \%$ of the cats showed no seroreactivity or evident parasites in the lymphoid organs and were diagnosed only when performing immunohistochemistry of the skin lesions. This reinforces the idea that in cats with clinical suspicion of the disease, several diagnostic techniques should be combined, including the cytopathological examination of the lymphoid organs, skin immunohistochemistry, and PCR.

There is disagreement among authors regarding the choice of the best lymphoid organ to perform BPA and subsequently cytopathological examination: whether it should be the bone marrow (VIDES et al., 2011) or the lymph node (COSTA et al., 2010). In dogs, it was already demonstrated that the bone marrow presents the higher density of Leishmania sp. during the clinical course of the disease (REIS et al., 2009). However, it is necessary to independently evaluate the BPA in both lymphoid organs to unequivocally define the best lymphoid organ for diagnosis.

PCR techniques are generally considered more specific than serology to diagnose leishmaniasis in cats ( MARTÍN-SÁNCHEZ et al., 2007; AYLLON et al., 2008; MAIA et al., 2008; TABAR et al., 2008). However, it should be kept in mind that depending on the stage of the disease (which affects parasitemia), it might be necessary to perform a PCR in lymphoid organs or skin and not in blood samples. In a comparative study between diagnostic methods assessing VL in dogs, it was concluded that amplification of L. chagasi kDNA may be detected even before seroconversion (ASSIS et al., 2010), which presents a detection threshold of $10^{-1}$ promastigotes $\mathrm{mL}^{-1}$ in blood samples of dogs artificially contaminated with $L$. chagasi, thus confirming the high sensitivity in relation to the serology assessed by ELISA and RIFI (NUNES et al., 2007).

Hence, the low reproducibility of results between different research groups illustrates the need for more accurate and standardized diagnostic techniques (ROSSI, 2007; BRESCIANI et al., 2010; SILVEIRA NETO et al., 2011; VIDES et al., 2011; SOBRINHO et al., 2012; CARDIA et al., 2013). 


\section{Final Considerations}

TL and VL in domestic cats is a daily reality in endemic areas and should never be underestimated in the clinical diagnosis following the observation of skin changes in cats. Although there is increasing evidence that cats can serve as reservoir for the parasite, its role in the epidemiological cycle of the disease and in public health issues requires further investigation. The standardization and validation of accurate and accessible diagnostic methods, which may be applied to epidemiological surveillance, are still required. With the combined evidences gathered thus far, the use of drastic measures, such as euthanasia of seropositive cats, may still be considered premature. However, random epidemiological studies in cats are highly recommended to form a better picture of the risks of cat leishmaniasis to public health.

\section{Acknowledgements}

This work was supported by the Fundação de Amparo à Pesquisa do Estado de São Paulo (FAPESP) [grant number 2010/51111-9]. We would like to thanks Isabel Pereira de Matos for checking all references included in this paper.

\section{References}

ADL, S. M.; SIMPSON, A. G.; LANE, C. E.; LUKEŠ, J.; BASS, D.; BOWSER, S. S.; BROWN, M. W.; BURKI, F.; DUNTHORN, M.; HAMPL, V.; HEISS, A.; HOPPENRATH, M.; LARA, E.; Le GALL, L.; LYNN, D. H.; McMANUS, H.; MITCHELL, E. A.; MOZLEYSTANRIDGE, S. E.; PARFREY, L. W.; PAWLOWSKI, J.; RUECKERT, S.; SHADWICK, R. S.; SCHOCH, C. L.; SMIRNOV, A.; SPIEGEL, F. W. The revised classification of eukaryotes. The Journal of Eukaryotic Microbiology, Lawrence, v. 59, n. 5, p. 429-493, 2012.

ALENCAR, J. E.; NEVES, J.; DIETZE, R. Leishmaniose visceral (Calazar). In: VERONEZI, R. Doenças infecciosas e parasitárias. 8. ed. Rio de Janeiro: Guanabara Koogan, 1991. p. 706-717.

ALVAR, J.; VÉLEZ, I. D.; BERN, C.; HERRERO, M.; DESJEUX, P.; CANO, J.; JANNIN, J.; Den BOER,
M. WHO Leishmaniasis Control Team.Leishmaniasis worldwide and global estimates of its incidence. PLoS One, v. 7, n. 5, p. e35671. 2012.

ASHFORD, R. W. The leishmaniases as emerging and reemerging zoonoses. International Journal for Parasitology, New York, v. 30, n. 12-13, p. 1269-1281, 2000.

ASSIS, J.; QUEIRÓZ, N. M. G. P.; SILVEIRA, R. C. V.; NUNES, C. M.; OLIVEIRA, T. M. F. S.; NORONHA JÚNIOR, A. C. F.; NEVES, M. F.; MACHADO, R. Z.; BUZETTI, W. A. S. Estudo comparativo dos métodos diagnósticos para leishmaniose visceral em cães oriundos de Ilha Solteira, SP. Revista Brasileira de Parasitologia Veterinária, Jaboticabal, v. 19, n. 1, p. 17-25, 2010.

AYLLON, T.; TESOURO, M. A.; AMUSATEGUI, I.; VILLAESCUSA, A.; RODRIGUEZ-FRANCO, F.; SAINZ, A. Animal serologic and molecular evaluation of Leishmania infantum in cats from Central Spain. Annals of the New York Academy of Sciences, New York, v. 1149, p. 361-364, 2008.

BAÑULS, A. L.; HIDE, M.; PRUGNOLLE, F. Leishmania and the leishmaniases: a parasite genetic update and advances in taxonomy, epidemiology and pathogenicity in humans. Advances in Parasitology, London, v. 64, p. 1-109, 2007.

BEZ, M.; CHAUVE, C. M. La Leishmaniose chez le chat: enquete sero-epidemiologique dans les Alpes-Maritimes. 1992. Thèse (Doctorat en Médecine Vétérinaire) Université de Lyon, Lyon.

BOLETIM EPIDEMIOLÓGICO PAULISTA - BEPA. Classificação epidemiológica dos municípios para a leishmaniose visceral americana. Estado de São Paulo, abril de 2008, v. 5, n. 52, p. 20-26, 2008.

BONFANTE-GARRIDO, R.; VALDIVIA, O.; TORREALBA, J.; GARCÍA, M. T.; GARÓFALO, M. M.; URDANETA, I.; URDANETA, R.; ALVARADO, J.; CUPOLLILLO, E.; MOMEN, H.; GRIMALDI JÚNIOR, G. Cutaneous leishmaniasis in cats (Felis domesticus) caused by Leishmania (Leishmania) venezuelensis. Revista Cientifica FCV-LUZ, Maracabo Venezuela, v. 6, n. 3, p. 187-190, 1996.

BRASIL. Ministério da Saúde. Secretaria de Vigilância em Saúde. Departamento de Vigilância Epidemiológica. Atlas de leishmaniose tegumentar americana: diagnósticos clínico. Brasília: MS, 2006. 136 p. Disponível em: <http://bvsms.saude.gov.br/bvs/ publicacoes/atlas_lta.pdf>. Acesso em: 06 fev. 2015.

Ministério da Saúde. Secretaria de Vigilância em Saúde. Departamento de Vigilância Epidemiológica. Manual de vigilância e controle da Leishmaniose 
Visceral. Brasília: Ministério da Saúde, 2014.120p. Disponível em: <http://bvsms.saude.gov.br/bvs/ publicacoes/manual_vigilancia_controle_leishmaniose_ visceral_1edicao.pdf $\bar{f}$. Acesso em: 06 fev. 2015.

Ministério da Saúde. Secretaria de Vigilância em Saúde. Departamento de Vigilância Epidemiológica. Manual de vigilância e controle da Leishmaniose Visceral. Brasília: Editora do Ministério da Saúde, 2006. 120 p. Disponível em: <http://bvsms.saude.gov.br/bvs/ publicacoes/manual_vigilancia_controle_leishmaniose_ visceral.pdf $>$. Acesso em 06 fev. 2014.

Ministério da Saúde. Secretaria de Vigilância em Saúde. Departamento de Vigilância Epidemiológica. Manual de vigilância da Leishmaniose Tegumentar Americana, 2. ed. Brasília: Ministério da Saúde, 2007. 180p. Disponível em: <http://bvsms.saude.gov.br/bvs/ publicacoes/manual_vigilancia_leishmaniose_2ed.pdf $>$. Acesso em 06 fev. 2014.

BRESCIANI, K. D. S.; SERRANO, A. C. M.; De MATOS, L. V. S.; SAVANI, E. S. M. M.; D’AURIA, S. R. N.; PERRI, S. H. V.; BONELLO, F. L.; COELHO, W. M. D.; AOKI, C. G.; COSTA, A. J. Ocorrência de Leishmania spp. em felinos do município de Araçatuba, SP. Revista Brasileira de Parasitologia Veterinária, Jaboticabal, v. 19, n. 2, p. 127-129, 2010.

CÂNDIDO, T. C. Comparação entre os métodos de ELISA-antígeno total e ELISA-ligante de fucose e manose em cães sintomáticos e oligossintomáticos para leishmaniose visceral. 2007. Dissertação (Mestrado em Ciência Animal) - Faculdade de Medicina Veterinária de Araçatuba, UNESP, Araçatuba.

CARDIA, D. F.; CAMOSSI, L. G.; SILVEIRA-NETO, L.; LANGONI, H.; BRESCIANI, K. D. Prevalence of Toxoplasma gondii and Leishmania spp. infection in cats from Brazil. Veterinary Parasitology, Amsterdam, v. 197, n. 3-4, p. 634-637, 2013.

CARDOSO, L.; LOPES, A. P.; SHERRY, K.; SCHALLIG, H.; SOLANO-GALLEGO, L. Low seroprevalence of Leishmania infantum infection in cats from northern Portugal based on DAT and ELISA. Veterinary Parasitology, Amsterdam, v. 174, n. 1-2, p. 37-42, 2010.

CASTRO, A. G. Controle, diagnóstico e tratamento da leishmaniose visceral (calazar). 2. ed. Brasília: Fundação Nacional de Saúde, 1996. 88 p.

CENTRO DE VIGILÂNCIA EPIDEMIOLÓGICA DO ESTADO DE SÃO PAULO - CVE. Distribuição do número de casos e óbitos de LVA segundo município e GVE de infecção. Estado de São Paulo, 2010 a 2013. 2013. Disponível em: <http://www.cve.saude.sp.gov.br/ htm/zoo/lvah_lpi.htm>. Acesso em: 18 nov. 2013.

CHAGAS, A. W. Criação de flebotomos e transmissão experimental da Leishmaniose visceral americana. Memórias do Instituto Oswaldo Cruz, Rio de Janeiro, v. 35, n. 2, p. 327-333, 1940.

CHAGAS, E.; FERREIRA, L. C.; DEANE, G.; DEANE, L.; GUIMARÃES, N. Leishmaniose visceral americana. II. Estudos epidemiológicos. Memórias do Instituto Oswaldo Cruz, Rio de Janeiro, v. 33, n. 1, p. 138-206, 1938.

COELHO, W. M.; RICHINI-PEREIRA, V. B.; LANGONI, H.; BRESCIANI, K. D. Molecular detection of Leishmania sp. in cats (Felis catus) from Andradina Municipality, São Paulo State, Brazil. Veterinary Parasitology, Amsterdam, v. 176, n. 2-3, p. 281-282, 2011.

COSTA, T. A. C.; ROSSI, C. N.; LAURENTI, M. D.; GOMES, A. A. D.; VIDES, J. P.; SOBRINHO, L. S. V.; MARCONDES, M. Ocorrência de leishmanioses em gatos de área endêmica para leishmaniose visceral. Brazilian Journal of Veterinary Research and Aninal Science, São Paulo, v. 47, n. 3, p. 213-217, 2010.

CUPOLILlO, E.; MEDINA-ACOSTA, E.; NOYES, H.; MOMEN, H.; GRIMALDI JÚNIOR, G. A revised classification for Leishmania and Endotrypanum. Parasitology Today, Amsterdam, v. 16, n. 4, p. 142-144, 2000.

DAHER, E. F.; FONSECA, P. P.; GERHARD, E. S.; SILVA LEITÃO, T. M.; SILVA JÚNIOR, G. B. Clinical and epidemiological features of visceral leishmaniasis and HIV co-infection in fifteen patients from Brazil. The Journal of Parasitology, Lawrence, v. 95, n. 3, p. 652655, 2009.

FREITAS, E. de; MELO, M. N.; Da COSTA-VAL, A. P.; MICHALICK, M. S. Transmission of Leishmania infantum via blood transfusion in dogs: potential for infection and importance of clinical factors. Veterinary Parasitology, Amsterdam, v. 137, n. 1-2, p. 159-167, 2006.

DEANE, L. M. Leishmaniose visceral no Brasil: estudos sobre reservatórios e transmissores realizados no Estado do Ceará. 1956. Tese (Livre Docência) - Universidade de São Paulo, São Paulo.

DESJEUX, P. Leishmaniasis: current situation and new perspectives. Comparative Immunology, Microbiology and Infectious Diseases, Elmsford, v. 27, n. 5, p. 305318, 2004. 
DIAKOU, A.; PAPADOPOULOS, E.; LAZARIDES K. Specific anti-Leishmania spp. antibodies in stray cats in Greece. Journal of Feline Medicine and Surgery, Philadelphia, v. 11, n. 8, p. 728-730, 2009.

FIGUEIREDO, F. B.; BONNA, I. C. F.; NASCIMENTO, L. D.; COSTA, T.; BAPTISTA, C.; PACHECO, T. M. V.; AMENDOEIRA, M. R. R.; MADEIRA, M. F. Avaliação sorológica para detecção de anticorpos anti-Leishmania em cães e gatos no bairro de Santa Rita de Cássia, Município de Barra Mansa, Estado do Rio de Janeiro. Revista da Sociedade Brasileira de Medicina Tropical, Uberaba, v. 42, n. 2, p. 141-145, 2009.

FRAGA, J.; MONTALVO, A. M.; De DONCKER, S.; DUJARDIN, J. C.; VAN DER AUWERA, G. Phylogeny of Leishmania species based on the heat-shock protein 70 gene. Infection, Genetics and Evolution: Journal of Molecular Epidemiology and Evolutionary Genetics in Infectious Diseases, Irvine, v. 10, n. 2, p. 238-245, 2010.

GENARO, O. Leishmaniose visceral canina experimental. 1993. Tese (Doutorado em Parasitologia) - Universidade Federal de Minas Gerais, Belo Horizonte.

GIMENO-ONDOVILLA, A. Contribución a la epidemiologia del kala-azar. Tropical Disease Bulletin, Oxfordshire, v. 30, n. 11, p. 752, 1933.

GIORDANO, A. Le chat dans la transmission de la leishmaniose viscérale de la médittéranée. Bollettino della Sezione Italiana. Società Internazionale di Microbiologia, Milano, v. 5, p. 300-332, 1933.

GONTIJO, C. M. F.; MELO, M. N. Leishmaniose visceral no Brasil: quadro atual, desafios e perspectivas. Revista Brasileira de Epidemiologia, São Paulo, v. 7, n. 3, p. 338-349, 2004.

HATAM, G. R.; ADNANI, S. J.; ASGARI, Q.; FALLAH, E.; MOTAZEDIAN, M. H.; SADJJADI, S. M.; SARKARI, B. First report of natural infection in cats with Leishmania infantum in Iran. Vector Borne and Zoonotic Diseases, Larchmont, v. 10, n. 3, p. 313-316, 2010.

HERVÁS, J.; CHACON-MANRIQUE DE LARA, F.; SÁNCHEZ-ISARRIA, M. A.; PELISSER, S.; CARRASCO, L.; CASTILLO, J. C.; GOMEZVILLAMANDOS, J. C. Two cases of feline visceral and cutaneous leishmaniasis in Spain. Journal of Feline Medicine and Surgery, Philadelphia, v. 1, n. 2, p. 101105, 1999.

KOUTINAS, A. F.; SARIDOMICHELAKIS, M. N.; MYLONAKIS, M. E.; LEONTIDES, L.; POLIZOPOULOU, Z.; BILLINIS, C.; ARGYRIADIS, D.; DIAKOU, N.; PAPADOPOULOS, O. A randomised, blinded, placebo-controlled clinical trial with allopurinol in canine leishmaniosis. Veterinary Parasitology, Amsterdam, v. 98, n. 4, p. 247-61, 2001.

LEIVA, M.; LLORET, A.; PEÑA, T.; ROURA, X. Therapy of ocular and visceral leishmaniais in a cat. Veterinary Ophthalmology, Oxford, v. 8, n. 1, p. 71-75, 2005.

LIMA, V. M. F.; BIAZZONO, L.; SILVA,A.C.; CORREA, A. P. F. L.; LUVIZZOTO, M. C. R. Serological diagnosis of visceral leishmaniasis by an enzyme immunoassay using protein A in naturally infected dogs. Brazilian Journal of Veterinary Research and Animal Science, São Paulo, v. 25, n. 4, p. 215-218, 2005.

LONGONI, S. S.; LÓPEZ-CESPEDES, A.; SÁNCHEZMORENO, M.; BOLIO-GONZALEZ, M. E.; SAURIARCEO, C. H.; RODRÍGUEZ-VIVAS, R. I.; MARÍN, C. Detection of different Leishmania spp. and Trypanosoma cruzi antibodies in cats from the Yucatan Peninsula (Mexico) using an iron superoxide dismutase excreted as antigen. Comparative Immunology, Microbiology and Infectious Diseases, Elmsford, v. 35, n. 5, p. 469-476, 2012.

LUVIZOTTO, M. C. R.; BIAZZONO, L.; EUGENIO, F. R.; ANDRADE, A. L. Leishmaniose visceral canina autóctone no município de Araçatuba-SP. In: CONGRESSO BRASILEIRO DE CLÍNICOS VETERINÁRIOS DE PEQUENOS ANIMAIS, 20., 1999, Águas de Lindóia. Anais... Águas de Lindóia: Anclivepa, 1999. p. 24-25.

MAIA, C.; NUNES, M.; CAMPINO, L. Importance of cats in zoonotic leishmaniasis in Portugal. Vector Borne and Zoonotic Diseases, Larchmont, v. 8, n. 4, p. 555-559, 2008.

MAIA-ELKHOURY, A. N. S.; ALVES, W. A.; SOUSAGOMES, M. L.; SENA, J. M.; LUNA, E. A. Visceral leishmaniasis in Brazil: trends and challenges. Caderno de Saúde Pública, Rio de Janeiro, v. 24, n. 12, p. 29412947, 2008.

MAROLI, M.; PENNISI, M. G.; DI MUCCIO, T.; KHOURY, C.; GRADONI, L.; GRAMICCIA, M. Infection of sandflies by a cat naturally infected with Leishmania infantum. Veterinary Parasitology, Amsterdam, v. 145, n. 3-4, p. 357-360, 2007.

MARTÍN-SÁNCHEZ， J.; ACEDO, C.; MUÑOZPÉREZ, M.; PESSON, B.; MARCHAL, O.; MORILLASMÁRQUEZ, F. Infection by Leishmania infantum in cats: epidemiological study in Spain. Veterinary Parasitology, Amsterdam, v. 145, n. 3-4, p. 267-273, 2007. 
MICHAEL, S. A.; MORSY, T. A.; El-SEOUD, S. F.; SALEH, M. S. Leishmaniasis antibodies in stray cats in Ismailiya Governorate Egypt. Journal of the Egyptian Society of Parasitology, Cairo, v. 12, n. 1, p. 283-286, 1982.

MOREIRA, M. A. B.; LUVIZOTTO, M. C. R.; NUNES, C. M.; SILVA, T. C. C.; LAURENTI, M. D.; CORBETT, C. E. P. Aplicação da técnica de imunofluorescência direta para o diagnóstico da leishmaniose visceral canina em aspirado de linfonodo. Brazilian Journal of Veterinary Research and Animal Science, São Paulo, v. 39, n. 2 p. 103-106, 2002.

MORSY, T. A.; ABOU-EL-SEOUD, S. M. Natural infection in two pet cats in a house of a zoonotic cutaneous leishmaniasis patient in Imbaba area, Giza Governorate, Egypt. Journal of the Egyptian Society of Parasitology, Cairo, v. 24, n. 1, p. 199-204, 1994.

MORSY, T. A.; MICHAEL, S. A.; EL DISI, A. M. Cats as reservoir hosts of human parasites in Amman, Jordan. Journal of the Egyptian Society of Parasitology, Cairo, v. 10, n. 1, p. 5-18, 1980.

MORSY, T. A.; MICHAEL, S. A.; MAKHLOUF, L. M.; el SIBAI, M. M. Leishmania infection sought in non human hosts in Suez governorate, Egypt. Journal of the Egyptian Society of Parasitology, Cairo, v. 18, n. 2, p. 539-545, 1988.

NASEREDDIN, A.; SALANT, H.; ABDEEN, Z. Feline leishmaniasis in Jerusalem: serological investigation. Veterinary Parasitology, Amsterdam, v. 158, n. 4, p. 364369, 2008.

NUNES, C. M.; DIAS, A. K. K.; GOTTARDI, F. P.; de PAULA, H. B. de; AZEVEDO, M. A. A. de; LIMA, V. M. F.; GARCIA, J. F. Avaliação da reação em cadeia pela polimerase para diagnóstico da leishmaniose visceral em sangue de cães. Revista Brasileira de Parasitologia Veterinária, Jaboticabal, v. 16, n. 1, p. 5-9, 2007.

OZON, C.; MARTY, P.; PRATLONG, F.; BRETON, C.; BLEIN, M.; LELIËVRE, A.; HASS, P. Disseminated feline leishmaniasis due to Leishmania infantum in Southern France. Veterinary Parasitology, Amsterdam, v. 75, n. 2-3, p. 273-277, 1998.

PINELLI, E.; KILLICK-KENDRICK, R.; WAGENAAR, J.; BERNADINA, W.; del REAL, G.; RUITENBERG, J. Cellular and humoral immune responses in dogs experimentally and naturally infected with Leishmania infantum. Infection and Immunity, Washington, v. 62, n. 1, p. 229-235, 1994.

PENNISI, M. G. A high prevalence of feline leishmaniasis in Southern Italy. In: INTERNATIONL CANINE LEISHMANIASIS FORUM, 2., 2002, Sevilla. Proceedings... Sevilla: Intervet, 2002. p. 39-48.
PENNISI, M. G.; LUPO, T.; MALARA, D.; MASUCCI, M.; MIGLIAZZO, A.; LOMBARDO, G. Serological and molecular prevalence of Leishmania infantum infection in cats from Southern Italy. Journal of Feline Medicine and Surgery, Philadelphia, v. 17, n.14, p. 656-657, 2012.

PENNISI, M. G.; MAXIA, I.; VITALE, F.; MASUCCI, M.; BORRUTO, G.; CARACAPPA, S. Studio dell'infezione de Leishmania mediante PCR in gatti che vivono in zona endemica. Atti della Società Italiana delle Scienze Veterinarie, Veneza, v. 54, p. 215-216, 2000.

PENNISI, M. G.; VENZA, M.; REALE, S.; VITALE, F.; LO GIUDICE, S. Case report of leishmaniasis in four cats. Veterinary Research Communications, Philadelphia, v. 28, p. 363-366, 2004. Supplement 1.

POLI, A.; ABRAMO, F.; BARSOTTI, P.; LEVA, S.; GRAMICCIA, M.; LUDOVISI, A.; MANCIANTI, F. Feline leishmaniosis due to Leishmania infantum in Italy. Veterinary Parasitology, Amsterdam, v. 106, n. 3, p. 181191, 2002.

READY, P. D. Biology of phlebotomine sand flies as vectors of disease agents. Annual Review of Entomology, Palo Alto, v. 58, p. 227-250, 2013.

REIS, A. B.; MARTINS-FILHO, O. A.; TEIXEIRACARVALHO, A.; GIUNCHETTI, R. C.; CARNEIRO, C. M.; MAYRINK, W.; TAFURI, W. L.; CORRÊAOLIVEIRA, R. Systemic and compartmentalized immune response in canine visceral leishmaniasis. Veterinary Immunology and Immunopathology, Amsterdam, v. 128, n. 1-3, p. 87-95, 2009.

ROSSI, C. N. Ocorrência de Leishmania spp. em gatos do município de Araçatuba, São Paulo, Brasil. 2007. Dissertação (Mestrado em Ciência Animal) - Faculdade de Medicina Veterinária de Araçatuba, Araçatuba.

ROSYPAL, A. C.; TROY, G. C.; ZAJAC, A. M.; FRANK, G.; LINDSAY, D. S. Transplacental transmission of a North American isolate of Leishmania infantum in an experimentally infected beagle. The Journal of Parasitology, Lawrence, v. 91, n. 4, p. 970-972, 2005.

ROUGERON, V.; CATZEFLIS, F.; HIDE, M.; De MEEÛS, T.; BAÑULS, A. L. First clinical case of cutaneous leishmaniasis due to Leishmania (Viannia) braziliensis in a domestic cat from French Guiana. Veterinary Parasitology, Amsterdam, v. 181, n. 2-4, p. 325-328, 2011.

RÜFENACHT, S.; SAGER, H.; MULLER, N.; SCHAERER, V.; HEIER, A.; WELLE, M. M.; ROOSJE, P. J. Two cases of feline leishmaniosis in Switzerland. Veterinary Record, London, v. 156, n. 17, p. 542-545, 2005. 
SANTOS, S. O. dos; ARIAS, J.; RIBEIRO, A. A.; PAIVA HOFFMANN, M. de; FREITAS, R. A. de; MALACCO, M. A. Incrimination of Lutzomyia cruzi as a vector of American visceral leishmaniasis. Medical and Veterinary Entomology, Boston, v. 12, n. 3, p. 315-317, 1998.

SARAIVA, L.; CARVALHO, G. M.; GONTIJO, C. M.; QUARESMA, P. F.; LIMA, A. C.; FALCAO, A. L.; ANDRADE FILHO, J. D. Natural infection of Lutzomyia neivai and Lutzomyia sallesi (Diptera: Psychodidae) by Leishmania infantum chagasi in Brazil. Journal of Medical Entomology, Honolulu, v. 46, n. 5, p. 11591163, 2009.

SAVANI, E. S. M. M.; OLIVEIRA CAMARGO, M. C. G.; CARVALHO, M. R.; ZAMPIERI, R. A.; SANTOS, M. G.; D'AURIA, S. R. M.; SHAW, J. J.; FLOETERWINTER, L. M. The first Record in the Americas of an autochthonous case of Leishmania (Leishmania) infantum chagasi in a domestic cat (Felis catus) from Cotia County, São Paulo State, Brazil. Veterinary Parasitology, Amsterdam, v. 120, n. 3, p. 229233, 2004.

SCHÖNIAN, G.; MAURICIO, I.; CUPOLILLO, E. Is it time to revise the nomenclature of Leishmania? Trends in Parasitology, Philadelphia, v. 26, n. 10, p. 466-469, 2010.

SCHUBACH, T. M. P.; FIGUEIREDO, F. B.; PEREIRA, S. A.; MADEIRA, M. F.; SANTOS, I. B.; ANDRADE, M. V.; CUZZI, T.; MARZOCHI, M. C. A.; SCHUBACH, A. American cutaneous leishmaniasis in two cats from Rio de Janeiro, Brazil: first report of natural infection with Leishmania (Viannia) braziliensis. Transactions of the Royal Society of Tropical Medicine and Hygiene, London, v. 98, n. 3, p. 165-167, 2004.

SERGENT, E. D.; SERGENT, E. T.; LOMBARD, J.; QUILICHINI, M. La leishmaniose à Alger. Infection simultanée d'un enfant, d'un chien et d'un chat dans la même habitation. Bulletin de Société de Pathologie Exotique, Paris, v. 5, n. 2, p. 93-98, 1912.

SERRANO, A. C. M.; NUNES, C. M.; SAVANI, E. S. M. M.; D’ÁURIA, S. R N.; BONELLO, F. L.; VASCONCELOS, R. O.; LIMA, V. M. F.; BRESCIANI, K. D. S. Leishmaniose em felino na zona urbana de Araçatuba, SP - relato de caso. Clínica Veterinária, São Paulo, v. 13, n. 76, p. 36-40, 2008.

SHERLOCK, I. A. Ecological interactions of visceral leishmaniasis in the States of Bahia, Brazil. Memórias do Instituto Oswaldo Cruz, Rio de Janeiro, v. 91, n. 6, p. 671-683, 1996.
SILVA, A. V. M. da; CÂNDIDO, C. D. D.; PEREIRA, D. P.; BRAZIL, R. P.; CARREIRA, J. C. A. The first record of american visceral leishmaniasis in domestic cats from Rio de Janeiro, Brazil. Acta Tropica, Amsterdam, v. 105, n. 1, p. 92-94, 2008.

SILVA, F. L.; OLIVEIRA, R. G.; SILVA, T. M.; XAVIER, M. N.; NASCIMENTO, E. F.; SANTOS, R. L. Venereal transmission of canine visceral leishmaniasis. Veterinary Parasitology, Amsterdam, v. 160, n. 1-2, p. 55-59, 2009.

SILVA, S. M. da; RABELO, P. F.; GONTIJO N. F.; RIBEIRO, R. R.; MELO, M. N.; RIBEIRO, V. M.; MICHALICK, M. S. First report of infection of Lutzomyia longipalpis by Leishmania (Leishmania) infantum from a naturally infected cat of Brazil. Veterinary Parasitology, Amsterdam, v. 174, n. 1-2, p. 150-154, 2010.

SILVEIRA-NETO, L.; SOBRINHO, L. S.; MARTINS, C. O.; MACHADO, R. Z.; MARCONDES, M.; LIMA VMF. Use of crude, FML and rK39 antigens in ELISA to detect anti-Leishmania spp. antibodies in Felis catus. Veterinary Parasitology, Amsterdam, v. 177, n. 3-4, p. 374-377, 2011.

SIMÕES-MATTOS, L.; MATTOS, M. R. F.; RODRIGUES, T. P.; PRATA JUNIOR, J. C. R.; TEIXEIRA, M. J.; SILVA, T. F. P.; HOLANDA, C. M.; PEREIRA, B. S.; LOPES, C. A. P.; POMPEU, M. M. L. Survey of anti-Leishmania chagasi antibodies in stray cats (Felis catus) in the city of Fortaleza, Northeast of Brazil. Revista Ciência Animal, Santa Maria, v. 11, p. 7981, 2001. Supplement 2.

SIMÕES-MATTOS, L.; MATTOS, M. R. F.; TEIXEIRA, M. J.; OLIVEIRA-LIMA, J. W.; BEVILAQUA, C. M. L.; PRATA JUNIOR, R.; HOLANDA, C. M.; RONDON, F. M. C.; BASTOS, K. M. S.; COÊLHO, Z. C. B.; COÊLHO, I. C. B.; BARRAL, A.; POMPEU, M. M. L. The susceptibility of domestic cats (Felis catus) to experimental infection with Leishmania braziliensis. Veterinary Parasitology, Amsterdam, v. 127, n. 3-4, p. 199-208, 2005.

SOBRINHO, L. S.; ROSSI, C. N.; VIDES, J. P.; BRAGA, E. T.; GOMES, A. A.; LIMA, V. M. F.; PERRI, S. H.; GENEROSO, D.; LANGONI, H.; LEUTENEGGER, C.; BIONDO, A. W.; LAURENTI, M. D.; MARCONDES, M. Coinfection of Leishmania chagasi with Toxoplasma gondii, Feline Immunodeficiency Virus (FIV) and Feline Leukemia Virus (FeLV) in cats from an endemic area of zoonotic visceral leishmaniasis. Veterinary Parasitology, Amsterdam, v. 187, n. 1-2, p. 302-306, 2012. 
SOLANO-GALLEGO, L.; RODRÍGUEZ-CORTÉS, A.; INIESTA, L.; QUINTANA, J.; PASTOR, J.; ESPADA, Y.; PORTÚS, M.; ALBEROLA, J. Cross-sectional serosurvey of feline leishmaniasis in ecoregions around the northwestern mediterranean. The American Journal of Tropical Medicine and Hygiene, Baltimore, v. 76, n. 4, p. 676-680, 2007.

SOUZA, A. I. de; BARROS, E. M.; ISHIKAWA, E.; ILHA, I. M.; MARIN, G. R.; NUNES, V. L. Feline leishmaniasis due to Leishmania (Leishmania) amazonensis in Mato Grosso do Sul State, Brazil. Veterinary Parasitology, Amsterdam, v. 128, n. 1-2, p. 41-45, 2005.

SOUZA, A. I. de; NUNES, V. L.; BORRALHO, V. M.; ISHIKAWA, E. Domestic feline cutaneous leishmaniasis in the municipality of Ribas do Rio Pardo, Mato Grosso do Sul state, Brazil: a case report. Journal of Venomous Animals and Toxins including Tropical Diseases, v. 15, n. 2, 2009. Available at: <http://www. scielo.br/scielo.php?script=sci_arttext\&pid=S167891992009000200017\&lng=en\&nrm=iso>. Accessed at: 01 apr. 2014.

TABAR, M. D.; ALTET, L.; FRANCINO, O.; SANCHEZ, A.; FERRER, L.; ROURA, X. Vector-borne infections in cats: molecular study in Barcelona area (Spain). Veterinary Parasitology, Amsterdam, v. 151, n. 2-4, p. 332-336, 2008.
TRAINOR, K. E.; PORTER, B. F.; LOGAN, K. S.; HOFFMAN, R. J.; SNOWDEN, K. F. Eight cases of feline cutaneous leishmaniasis in Texas. Veterinary Pathology, Basel, v. 47, n. 6, p. 1076-1081, 2010.

VAN DER AUWERA, G.; FRAGA, J.; MONTALVO, A. M.; DUJARDIN, J. C. Leishmania taxonomy up for promotion? Trends in Parasitology, Philadelphia, v. 27, n. 2, p. 49-50, 2011.

VIDES, J. P.; SCHWARDT, T. F.; SOBRINHO, L. S.; MARINHO, M.; LAURENTI, M. D.; BIONDO, A. W.; LEUTENEGGER, C.; MARCONDES, M. Leishmania chagasi infection in cats with dermatologic lesions from an endemic area of visceral leishmaniosis in Brazil. Veterinary Parasitology, Amsterdam, v. 178, n. 1-2, p. 22-28, 2011.

VITA, S.; AGUZZI, I.; PETROTTA, E.; LUCIANI, A. Feline leishmanisis and ehrlichiosis: serological investigation in Abruzzo region. Veterinary Research Communications, Philadelphia, v. 29, p. 319-321, 2005. Supplement 2.

WORLD HEALTH ORGANIZATION - WHO. Control of the leishmaniases. Report of a meeting of the WHO Expert Committee on the Control of Leishmaniases. Geneva, 22-26 mar. 2010.

- Report of fifth consultative meeting on Leishmania/HIV coinfection, Addis Abada, Etiópia, 2022 mar. 2007. 